\title{
Alışveriş Merkezlerinde Ortak Kullanımlı Yemek Alanlarının Tasarım Kriterleri
}

\author{
Gülşah Karyağdi $1^{*}$ \\ 1* Beykent Üniversitesi, Mühendislik-Mimarlık Fakültesi, İç Mimarlık (TR) Bölümü, İstanbul, Türkiye, (ORCID: 0000-0002-5377-1074), gulsahkaryagdi@beykent.edu.tr
}

(Illk Geliş Tarihi 6 Temmuz 2020 ve Kabul Tarihi 10 Ekim 2020)

(DOI: 10.31590/ejosat.765304)

ATIF/REFERENCE: Karyağdı, G. (2020). Alışveriş Merkezlerinde Ortak Kullanımlı Yemek Alanlarının Tasarım Kriterleri. Avrupa Bilim ve Teknoloji Dergisi, (20), 254-259.

\section{$\ddot{O} \mathbf{z}$}

Alı̧̧veriş, insanlar arasında iletişimi sağlayan en eski sosyal eylemlerden biri olmakla beraber, tarih boyunca içinde bulunduğu coğrafyaya göre farklılıklar göstermiştir. Toplumların kültürel yapısı, yaşam koşulları, yönetim şekilleri alışveriş mekânlarının oluşumunu ve birbirleriyle olan ilişkilerini etkilemiştir. Avrupa şehirlerinin büyük çoğunluğunda 20. yüzyılın ikinci yarısından sonra dünya savaşlarının ardından strüktürel ve kültürel yeni bir yapılanma başlamışıı. Yaşam standartlarının yükselmeye başlaması, motorlu araçların yaygınlaşması, kadınların iş hayatında daha aktif yer almaya başlaması, rekabetin artması, bireysel girişimciliğin önem kazanması bu yapılanmaların itici güçleri olmaya başlamıştır. Aynı zamanda moda gibi kavramların önem kazanması, bireysel kimlik toplu iletişim araçları ile farklı bir etkileşim içersine girerek bireysel kimliğin tüketim ürünleri ile tariflenmesi öne çıkmıştır. $\mathrm{Bu}$ dönüşüm birçok bilimsel çalışmaları, araştırmaları ve deneyleri beraberinde getirmektedir. Şehirlerin ekonomik gelişminde ve tüketim imkânlarının kolaylaşmasında önemli bir yere sahip olan ve önemli ekonomik yatırımlar gerektiren alışveriş merkezleri kentsel strüktürü, alt ve üst yapıyı etkileyen yapılar olmaktadır. Alışveriş merkezleri toplumsal hayatta farklı bir sosyalleşme ortamı yaratmaktadır. Günümüz teknolojisi ile bu yapıların iç mekânlarını entegre etmek ve kullanıcılara yeni deneyimler kazandırmak ve farkındalık oluşturmak gerekmektedir. Çalı̧̧ma kapsamında tarihsel süreç içinde alışveriş eylemindeki değişim ve gelişimlerin alışveriş mekânları üzerindeki etkisi genel olarak incelenmiştir. Bu çalışmanın amacı, alışveriş merkezlerinde ortak kullanımlı yemek alanları tasarım ve düzenlemelerinin tüketici üzerindeki etkisini iç mimari açıdan tasarım kriterlerine yönelik vitrin/cephe, logo, aydınlatma tasarımı, malzeme seçimi, mobilya tasarımı/kullanımı başlıkları altında incelemektir. Araştırma kapsamında bilgi toplama, nitel analiz yöntemi kullanılmıştır. Bu bağlamda ortak yemek alan düzenlemelerinin tüketici eğilimlerini nasıl etkilediğini incelemekle beraber insan eğilimlerinin malzeme, tasarım ve düzenleme ile nasıl bütünleştiğine dikkat çekmek hedeflenmektedir.

Anahtar Kelimeler: Alışveriş Merkezleri, Tasarım, Mobilya Tasarımı, AVM Yemek Alanı, İç Mekân.

\section{Design Criterias Of Food Court In Malls}

\begin{abstract}
Although shopping is one of the oldest social actionsthat provide communication between people, it has varied according to the geography it is in throughout history. The cultural structure of the societies, living conditions and forms of management have influenced the formation of the shopping places and their relations with each other. 20th century With the second half, a structural and cultural restructuring started in European cities after the world wars. The driving forces of these organizations have started to increase in living standards, the widespread of motor vehicles, the more active women take part in business life, the increase in competition, and the individual entrepreneurship gain importance. At the same time, concepts such as fashion gained importance and the definition of individual identity with consumer products under the influence of mass media became prominent. This transformation brings with it many scientific studies, researches and experiments. Shopping centers are structures that affect the urban structure, infrastructure and superstructure that require large economic investments. It creates a different socialization environment in social life. With today's technology, it is necessary to integrate the interiors of these structures and to provide new experiences and awareness to users. Within the scope of the study, the effects of changes and developments in the shopping action on the shopping places in the historical process have been generally examined. The aim of this study is to examine the effects of the design and arrangements of common use dining areas in the shopping malls on the consumer under the headings of showcase / facade, logo, lighting design, material selection, furniture design / use for design criteria. In the research, information gathering and qualitative analysis method were used. In this context, while examining how common dining arrangements affect consumer trends, it is aimed to draw attention to how human trends integrate with material, design and regulation.
\end{abstract}

Keywords: Shopping Centers, Design, Furniture Design, Food Court, Interior Space.

* Gülşah Karyağdı, Beykent Üniversitesi, Mühendislik-Mimarlık Fakültesi, İç Mimarlık (TR) Bölümü, İstanbul, Türkiye, (ORCID: 0000-0002-53771074) gulsahkaryagdi@beykent.edu.tr 


\section{Giriş}

Alışveriş, insanlar arasında iletişimi sağlayan en eski sosyal eylemlerden biri olmakla beraber tarih boyunca içinde bulunduğu coğrafyaya göre farklılıklar göstermiştir. Toplumların; kültürel yapısı, yaşam koşulları, yönetim şekilleri alışveriş mekânlarının oluşumunu ve birbirleriyle olan ilişkilerini etkilemiştir.

20. yy. dünyayı etkileyen savaşların yaşandığı bir çağ olmuş; Avrupa şehirlerinin birçoğunda dünya savaşları ve özellikle 20.yy. ikinci yarısından sonra strüktürel ve kültürel yeni bir yapılanma başlamıştır. Kentlerin savaş sonrasında yeniden inşası sırasında kent merkezleri, farklı alt merkezlerin bir araya geldiği birimlere dönüşmeye başlamıştır. Bu dönüşüm beraberinde bazı sorunları da getirmiştir. Özellikle şehirlerde yaşayan insanlar; sosyal, kültürel ve ticari aktivitelere erişimde sıkıntılar çekmeye başlamıştır. Bu nedenden dolayı XIX. yy. sonu ve XX. yy.'ın başlarında görülmeye başlanan alışveriş merkezleri, şehir merkezi yerine banliyölerde konumlandırılmıştır (Durukan, 2018). Alışveriş Merkezi tasarımcılarının öncülerinden olan Viktor Gruen 'alışveriş merkezlerinin bu gündelik hayatın getirdiği yüklerden bunalan insanlar için kaçış noktası olabildiğini' belirtmiştir ( Gruen, 1960). Alışveriş Merkezleri bu bakış açısıyla yapılandırılmaya başlanarak, insanların sadece alışveriş yapmaktan ziyade biraraya gelmek için kullandıkları mekânlar haline gelmişlerdir.

Alışveriş mekânları, kâr etme amacı ile kurulan ticari işletmeler olarak insan hayatında önemli bir yere sahiptir. Satış ve satıştan elde edilen kâr oranları, ticari işletmelerin varlıklarını sürdürebilmeleri için önemlidir. Bu yüzden satış ve kârlılığın sağlanabilmesi için, alışveriş ve günlük ihtiyaçları karşılayan, eğlence, iletişim ve etkileşimi bir araya getiren mekânlar tasarlanmaya başlanmıştır. Alışveriş eylemindeki değişiklikler yine alışveriş mekânlarındaki yapılanmayı etkilemiştir.

Günümüzde kolaylıkla bulunabilen, ulaşılabilen ürünler artık satış yapma zorunluluğunun ötesine geçerek, rekabetin arttığı ortamlarda alışveriş mekânlarını farklılaşmaya zorlamaktadır. Alışveriş mekânları tasarımında, mekânlara kimlik ve özgünlük ekleyecek disiplinler arası yaklaşım ve etkileşimlerin kullanılması gerekliliği ortaya çıkmıştır. Küresel perakende ve eğlence alanı, makro demografik eğilimler tarafından yönlendirilen kalıcı ve yapısal değişimlerden geçmektedir. $\mathrm{Bu}$ eğilim ve beklentilerin birleşimi, tüketici harcama modelleri ve alan tahsisi üzerinde, hem perakende hem de gıda hizmetleri sektörlerini küresel çapta etkilemektedir. Yapılan araştırmalar, yemek tüketimine harcanan tutarların diğer tüketim ihtiyaçlarına harcanandan daha fazla olduğunu göstermektedir. Stratejik olarak, alışveriş mekânları içinde yeme-içme alanlarının konumladırılması, bu mekânların daha çok rağbet görmesini sağlamaktadır (Pekpostalcı, 2015b). Bu gerçeklik ise yeme-içme sektörünün hızla gelişmesini ana faktör olarak karşımıza çıkmaktadır. Doğru bir uygulama yöntemi izlendiğinde, yeme-içme hizmetleri, dürtüyü, alışveriş mekânında kalış süresini, harcamaları ve genel satışı arttıran bir nitelik kazandırmaktadır.

Alışveriş merkezleri ortak yemek alanlarının tasarımında; insanı anlayan, ona hitap eden ve insan deneyimlerini temel alan doğru uygulamaların kullanımı müşteri bağlılığını sağlamaktadır. $\mathrm{Bu}$ çalışmanın amacı günümüz teknolojisi, değişen insan ihtiyaç ve eğilimlerine göre tasarlanmış ortak yemek alanlarının tasarım ve düzenlemelerini incelemektir. Tüketici eğilimlerinin malzeme, tasarım ve düzenleme ile nasıl bütünleştiğine dikkat çekmek hedeflenmektedir. Araştırma kapsamında bilgi toplama, nitel analiz yöntemi kullanılmıştır. $\mathrm{Bu}$ bağlamda çalışmada; tarihi perspektif içinde alışveriş kavramı ve alışveriş mekânlarının gelişimi, tüketici etkileşiminde öne çıkan faktörler ve alışveriş merkezlerinin ortak kullanımlı yemek alanlarının tasarım kriterleri incelenmiştir.

Bahsi geçen kriterlere göre tasarlanmış ortak yemek alanlarının müşteri memnuniyeti, müşteri bağlılığı ve kârlılık oranları konusunda alışveriş merkezlerinin genel kârlılık oranlarına katkı sağladığı görülmüştür.

\section{Alışveriş Merkezlerinin Gelişimine Genek Bakış}

İnsanların birbirleri ile karşılıklı yarar sağlayıcı ilişkilere girme eylemi olan alışveriş, ürün veya hizmetin elde edilmesidir. Tarihsel süreç içinde alışveriş eylemindeki gelişim ve değişimler, temel ihtiyaçların giderilmesinin dişına çıkarak, müşteri memnuniyeti ve statü kaygısının giderilmesini sağlamaya yönelik, gelen müşteriye tek merkezde hizmet vermek amaciyla özel olarak tasarlanmış alan ve yapıları etkileyerek eylemin yapıldığı mekânları geliştirmiştir. Doğan yeni ihtiyaçları karşılamak amacı ile düzenli, organize mekân ve yapılara ihtiyaç duyulmuştur.

MÖ 3000 yıllarından günümüze, insanların ihtiyaçlarını gidermek için gittikleri, ekonomik faaliyetlerin yürütüldüğü alışveriş mekânlarının ilk örneklerinden olan çarşı ve pazar yerleri zamanla agora, arasta, bedesten ve kapalı çarşılara dönüşmeye başlayıp günümüz büyük alışveriş merkezlerine kadar gelmiştir.

Endüstri Devrimi, 19. yüzyıldan sonra Avrupa'da kentleşme olgusunu güçlendirerek şehir merkezlerinde ticari ve iş hayatına ait merkezlerin ve alışveriş alanlarının artmasına neden olmuştur. Teknolojideki gelişmelerin etkisi ile kentin merkezinde daha büyük ve çok katlı ticaret, iş ve alışveriş mekânlarının yapılmasına başlanmıştır. Günlük perakende ve toptan alışverişin yapıldığı ilk büyük pazar yeri ve "Hall” için, Paris'te 1834 yılında inşa edilen Madeleine Market Hall, 1835 yılında Londra'da inşa edilen Hungerford Fish Market ve 1826 yılında yapılan Boston'da Faneuil Hall Pazar yeri örnek olarak göstermek mümkündür (Tokol, 1996).

Değişik türde ürünlerin, değişik gelir düzeyindeki müşteriye hizmet verecek şekilde pazarlandığı pazar ve hallerin gösterdiği değişim ve gelişim, büyük mağazaların oluşmasına etki etmişlerdir. Paris'te 1850'li yıllarda açılan Bon Marche (URL-1) adlı mağaza büyük mağaza alışveriş merkezi kavramına yaklaşan bir örnek oluşturmaktadır (Pekpostalc1, 2015a). Bu yüzyılda başarıya ulaşan büyük mağazalar Avrupa ve Amerika'da alışveriş merkezleri yapılmasına etki etmişlerdir.

Amerika'da 1916 yılında yapılan Market Square, planlı alışveriş merkezlerinin ilk örneği olarak gösterilmektedir. 1950'li yıllardaki bölgesel alışveriş merkezleri, alışveriş̧ merkezlerinin aslını oluşturmaktadır. 50'li ve 60'lı yıllar açık planlı olan bu merkezlerin terk edilmesi kapalı ve içe dönük tasarımların gelişmesine neden olmuştur. 20. yüzyıldaki gelişmeler alışveriş merkezlerinin tasarımını, müşteri kitlesini ve alışveriş kavramını etkilemiş ve beraberinde bu yapılara iyileştirmeler getirmiştir (Pekpostalc1, 2015a). 


\section{Alışveriş Merkezleri Tüketici Etkileșiminde Öne Çıkan Faktörler}

Tüketim, genel anlamda tüketicilerin ihtiyaç ve memnuniyeti sağlamak için mal ve hizmetlerin kullanılması olarak tanımlanmaktadır (Cochrane, Bell, 1956). Üreticiler daha önceki süreçlerde tüketicileri kontrol altında tutmakta iken, günümüzde değişen tüketici profili ve kültürü ile tüketiciler, üretimi kontrol altına almaya başlamışlardır. Tüketiciler ihtiyaçlarının sınırlarını belirlemekte, çeşitlendirmekte ve kişiselleştirmektedirler (Pekpostalcı, 2015a). Kültürel etkenler bireylerin temel istek ve ihtiyaçlarının nedeni veya temel belirleyicisi olup; insanların oluşturduğu değerler sistemi içerisindeki örf, adet, gelenek, görenekler, ahlaki değerler, tutum, sanat, inançlar bir toplumda ortak payda sembolleri olmakla birlikte yiyecek, içecek, binalar, mobilyalar ve araçgereçler gibi somut kavramlar ile eğitim, adalet, kanun, refah gibi soyut kavramları da kapsamaktadır. $\mathrm{Bu}$ faktörlerin tümü bireylerin harcama kararları üzerinde ciddi bir etkiye sahiptir (Sat1c1, 2000).

\subsection{Sosyolojik Faktörler}

Tüketici davranışları kültürel faktörlerin dışında aile, rol, statü gibi farklı sosyal ve çevresel faktörlerden de etkilenmektedir (Satıc1, 2000). Kolay ulaşılabilen, otoparkı olan, müşteri konforu göz önüne alınarak iklimlendirilmiş günümüz alışveriş merkezleri, perakende alışveriş, yeme-içme, eğlence olanaklarıyla çekim merkezleri haline gelmiştir.

Alışveriş merkezi konseptleri farklı tüketici gruplarına uygun, toplumsal faktörler göz önünde bulundurularak oluşturulmaktadır. Günümüz sistemleri, tüketicilerin neyi ne kadar harcayacaklarına karar vermelerini manipule etmekle bunu bir sosyal görev haline getirmektedir. Ekonomik yönden güçlü ülkelerde, tüketim sürekli artış halindedir ve bütün ülkelerde de sürekli teşvik halinde yükseltilmektedir. Kapitalist ekonomik sistem, yönetilebilir tüketici toplum ile beslenir. Sistem görevini yapıp tüketim toplumu oluştururken, tüketici eğilimlerinde değişimler gerçekleşmektedir. Tüketici eğiliminde oluşan değişimler, benmerkezci, makro düşünen ve ayrıntıya önem vermeyen klasik pazarlama anlayışını sona erdirmiş; tüketici odaklı, mikro düşünen ve ayrıntılara önem veren, tüketicilerin istek ve ihtiyaçlarından yola çıkarak başarılı olmaya çalışan modern pazarlama anlayışı önem kazanmıştır (Pekpostalcı, 2015a).

\subsection{Psikolojik Faktörler}

Genel anlamıyla "ruh bilimi" olarak tanımlanan psikoloji, bir kişiyi veya grubu etkileyen ve tanımlayan, duygu ve düşünce biçimlerin bütünü (Göka, 2001) olarak tarif edilmektedir. Bu tarif referans alınarak, mekân psikolojisini kişiyi ve grubu etkileyen duygu ve düşünme biçimlerine mekânın yapmış olduğu etki olarak tanımlamak doğru olacaktır (Göka, 2001). Yeni bir mekâna ait algının oluşmasında psikolojik olarak iki süreçten bahsetmek mümkündür. Bunlardan ilki duyumsal süreçtir. Duyumsal süreçte kişi ilk kez gördüğü mekâna ait deneyimlerini kazanır ve mekânsal algının ilk bölümü oluşur. İkinci aşamada ise zihinsel bir süreç devreye girerek zihinde kalan imgelerle mekânı tekrar tekrar yaşatabilmektedir (Özen, 2006). Alışveriş mekânı ile birey arasında bir duygusal birliktelik oluşturabilmek için mutluluğu, huzuru ve güveni temsil eden sembolik öğelerin tasarımla bütünsel olarak mekân içinde vurgulanması gerekmektedir. Alışveriş mekânlarının mimarisi de bu anlamda psikolojik olarak ele alınmalı ve tasarlanmalıdır (Pekpostalcı, 2015a).

\subsection{Ekonomik Faktörler}

Tüketim, ilk olarak satın alınan nesnelerin dayanıklılığına göre sinıflandırılmakla beraber dayanıklı tüketim malları, dayanıklı olmayan tüketim malları ve hizmetler olarak diğer başlıklar altında da incelenir. Gıda, giyim, konut, ısıtma ve enerji, sağlık, ulaşım, ev aletleri ve mobilya, iletişim ve teknoloji, eğitim, eğlence olarak, tüketimi karşılayacak ihtiyaçlara göre de sinıflandırılır. Küçük, orta ve büyük ölçekli tüketim sınıfı olmak üzere üç ana tüketim sınıfı bulunur. Küçük ölçekli tüketim sınıfının harcamalarının büyük bir kısmını yiyecekler oluştururken, orta ölçekli tüketim sınıfının harcamalarının büyük kısmı teknolojik ürünler ve yiyecekler oluşturur. Büyük ölçekli tüketim sınıfının harcamaları ise genellikle teknolojik ürünlerden oluşur (Aytıs, 2008). Tüketicinin harcama kararı, onun kişisel özelliklerinden, yaşı ve yaş döneminden, mesleğinden, ekonomik durumundan ve yaşam tarzından etkilenir. Tüketim günümüzde daha çok, kendini ifade etme ve kimlik oluşturma olarak bireyleri etkilemeye başlamıştır. Tüketim sınıflarında ilerlemek, tüketicinin sosyo/toplumsal yönü beslenerek daha prestijli bir standarda ulaşmak belirli bir sosyal statüyü kazanmak anlamına gelir.

\subsection{Teknolojik Faktörler}

Bilim ve teknolojiye kendisine sağladığ 1 faydalardan dolayı önem veren tüketici profili, eğilim olarak yalnız elektronik ve mekanik ürünlere değil, bilim ve teknolojiyi her anlamda kullanan tüm mal ve hizmet üreticilerine/markalara rağbet etmektedir. Teknolojik bağımlılığın neden olduğu ve insanların giderek daha çok ihtiyaç duyduğu toplumsal iletişim ve sosyalleşme arzusu, duyusal ve duygusal yaklaşımları beraberinde getirmektedir. Tasarımda kullanılan malzemelerin, üretim teknolojilerindeki gelişimi sonucu artan kalite ve çeşitlilik, kent merkezlerinde var olan geleneksel çarşı görünümlerine sahip mekânları, kapalı mekânlar içinde yaşatarak tüketicilerin hizmetine sunmaktadır. Bilim ve teknolojiyi kullanan firmalar başarı grafiklerindeki artışın devamlılığını sağlamaya yönelik teknolojik gelişmeleri yakından takip etmektedirler. Günümüzde yüz tanıma teknolojisi, akıllı aynalar, yapay zekâ kullanımı, artırılmış gerçeklik, robotik mağaza görevlileri ve sesli asistanların kullanımı gibi teknolojik gelişmeler, gündelik yaşantımızda daha çok söz konusu olmaya başlamıştır (Kaplanseren, 2020).

\subsection{Değişen Tüketici İhtiyaçları}

İnsan, içinde yaşadığı toplumun normları ve kurallarına göre yaşamını sürdüren sosyal bir varlıktır. Bir insan doğduğu andan itibaren içinde bulunduğu aile, arkadaş çevresi ve toplumdan gördüğü ve öğrendiği bilgiler doğrultusunda kodlanarak, kendine tanımlanan rollere bürünerek görevlerini yerine getirmek suretiyle hayatını şekillendirmektedir. Günümüz toplumu geçmişe kıyasla üretim toplumundan tüketim toplumu haline gelmiştir. Bocock'a göre insanların kim olduğu ve/veya kim olmak istedikleri ile ilgili duyarlılıklarını korumayı sağlayan yöntemleri tüketim etkilemektedir.

Günümüz alışveriş merkezleri, değişen tüketici ihtiyaçlarına cevap verebilmek için müşterilerine sinema, oyun alanları, eğlence alanları, dinlenme alanları, restoranlar gibi müşterilerin sosyal, kültürel, sportif etkinliklerine hitap eden birimleri bünyelerine katarak, geleneksel alışveriş kavramının ötesine 
geçmiştir. Tüketici beklentilerinin perakende sektörünün gelişimine paralel olarak sürekli değişmesi, yeni ürünler ve farklı hizmetlerin talep edilmesine neden olmakta ve tüketicilerin beklentilerinin karşılandığ 1 yerleri tercih etmesine sebep olmaktadır (Pekpostalc1, 2015a).

\section{Alışveriş Merkezlerinde Ortak Kullanımlı Yemek Alanlarının Tasarım Kriterleri}

Alışveriş mekânları, kâr etme amacı ile kurulan ticari işletmeler olarak insan hayatında önemli bir yere sahiptir. Satış ve kârlılığın sağlanabilmesi için, alışveriş ve günlük ihtiyaçları karşılayan, eğlence, iletişim ve etkileşimi bir araya getiren mekânlar tasarlanmaya başlanmıştır. Son yıllarda insanların dışarıda daha fazla yemek yemesi beraberinde yeme-içme sektörünün hızla gelişmesini sağlamış ve çeşitlilikler getirmiştir. Hızla gelişen yeme-içme sektörüne yönelik doğru uygulamalar, kullanıcı ihtiyaç ve taleplerinin karşılanması AVMler'de kalış süresinin, harcamaların ve genel satışın artmasını sağlayacaktır.

Alışveriş merkezleri ortak kullanımlı yemek alanlarının tasarımında, insanı anlayan, ona hitap eden ve insan deneyimlerini temel alan doğru uygulamalar, müşteri bağlılı̆̆ sağlar. Genellikle fast-food sağlayan birimlerden oluşan ortak kullanımlı yemek alanları, genç-yaşlı olmak üzere geniş bir müşteri kitlesinin ihtiyaçlarını karşılayabilmelidir (Coleman 2006). Bu nedenle, yiyecek-içecek satışı yapan birimlerin marka karmaları belirlenirken, yaşam tarzlarının farklı olduğu bireyler de göz önünde bulundurulmalı ve çeşitlilik sağlanmasına önem verilmelidir. İyi tasarlanmış ortak kullanımlı yemek alanları, marka karmasına ek olarak dükkân büyüklükleri, yerleri ve sayısını da içerir. Alışveriş merkezi ortak kullanımlı yemek bölümünde bulunan yemek satış birimlerinin hem hitap ettiği kesimle hem de diğer markalarla uyum içinde olması önemlidir (Coleman 2006).

Yemek bölümlerinin alışveriş merkezi içindeki konumları önemlidir. Kolaylıkla görülebilen, tanımlı ve her alanı kullanılmış, ana dolaşım alanları ile bağlantılı konumlandırılmalıdır. Yemek alanları, alışveriş merkezleri için birer çekim noktası oldukları için mümkün olduğunca birçok mağazanın yemek bölümlerinden algılanmasını sağlayacak çözümler göz önünde bulundurulmalıdır. Ortak kullanımlı yemek alanları, ortak bir oturma bölümü ve çevresinde yan yana, karşılıklı ya da tasarlanmış bir bölüm içinde dizilmiş olan açık cepheli yemek dükkânlarından oluşur. $\mathrm{Bu}$ dükkanlardan yararlanmak için sıraya giren, aradığını bulmak için gözlem yapan kişiler için yürüme, oturma ve sirkülasyon alanlarının belirlenmesi gerekmektedir (Coleman 2006).

Genel dolaşım alanlarında insanların aradıklarını kolayca bulabilmelerini sağlayacak yönlendirme, bilgilendirme tabelalarına yer verilmelidir. Alışveriş merkezi içerisinde kullanılan her türlü tabela ve görsel bina girişinden en üst kata kadar binanın mimarisi ile uyum içerisinde olmalı ve uygun bir şekilde tasarlanmalıdır. Standart özelliklere sahip olan ve evrensel kullanımı olan yön tabelalarında (acil çıkış, yangın, toplanma noktası, wc, kat planları, vb.) dil birliğine uygun tasarıma önem verilmelidir (Beddington 1991).

Alışveriş merkezleri ortak kullanımlı yemek alanları tasarımında malzeme seçimi, renk kullanımı ve oturma alanlarının kurgusu, müşteri konforunu arttırmaya yönelik çözümlenmelidir. Alışveriş merkezinde yer alan yemek bölümleri belli bir temaya sahip olmalı bunun da müşteri ilgi ve talebini artırıcı etkisine dikkat edilmelidir (ULI, 1999). Alışveriş̧ merkezlerinde ortak kullanımlı yemek alanlarının tasarımında vitrin/cephe, logo ve aydınlatma tasarımı, malzeme seçimi, mobilya tasarımı/kullanımı gibi tasarım kriterleri yer almaktadır.

\subsection{Vitrin/Cephe Tasarımı}

Yemek satış birimlerinin vitrin tasarımı, dükkân içinin daha iyi algılanmasını sağlayacak açıklık seviyesine sahip olmalıdır. Mağazaların diş cephesi müşterinin mağazaya ilişkin olumluolumsuz düşüncelerinin ilk, hatta bazen tek ipucu olabilmektedir (Arslan, 2004). Tek akslı dükkânlarda cephenin vitrin bölümleri mekân içinin tamamını görsel olarak dışarıdan algılanacak şekilde tasarlanmalıdır. Tamamen kapalı/duvar örülü vitrinler görüş açısını kısıtlamaktadır. Yemek satış birimlerinin cephesine yerleştirilecek teşhir ürünleri ve tasarım bu doğrultuda oluşturulmalıdır. Vitrin cephesinde bulunan logo alanı, giriş, tezgâh ve diğer alanların kesintisiz bir tasarımı olmalıdır. Çerçevesiz/çerçeveli cam sistem uygulamaları içinde tam yüksekliğin kullanıldığı modern tasarımların kullanılması önerilmektedir. Vitrin bazaları ortak alan süpürgelikleri hizasında bitirilmelidir.

\subsection{Logo Tasarımı}

Logolar ve marka isimleri algılanabilir şekilde marka kimliğine uygun olarak tasarlanmalı ve dükkânların cephe vitrin yüksekliği ve isimlik alanı tanımlanan alanlara, tanımlanan şekilde yerleştirilmelidir. Tüm logo alanını kaplayan, 1şık kutusu tipinde logolar yerine logo aydınlatması led armatürler ile minimum 1000 lux aydınlatma yapılmalı ve AVM'nin açık olduğu saatlerde logo 1şığı sürekli açık kalacak şekilde planlama yapılmalıdır. Logo yüksekliği tüm cephe tasarımı bütünlüğü ve cephenin görünürlüğü ile uyumlu olmalıdır. Bayi ismi, mağaza logosu ile aynı ölçülerde olmalı, daha belirgin olmamalıdır.

\subsection{Aydınlatma Tasarımı}

Ortak kullanımlı yemek alanlarında satış yapan kafe, kiosk ve restoranların aydınlatması ticari olarak satış alanının çekim gücünü artıran ve güçlendiren bir tasarım kriteri olarak görülmektedir. Müşterinin dikkatini çekme ve satış alanına yönlendirme açısından vitrin tasarımı ve aydınlatması özel olarak ele alınmalıdır. Vitrin aydınlatma tasarımında, dolaşım alanındaki ziyaretçilerde göz kamaşma problemi oluşması engellenmelidir. Aydınlık düzeyleri ise 400 lux tezgâh, 800 lux yiyecek sergileme bölümleri içi, 200 lux oturma alanları/dimmer opsiyonlu, 1200 lux logo aydınlatması için önerilmektedir. Servis edilen yiyecekler ve menü alanı maksimum seviyede aydınlatılmalıdır. Logo ve vitrin aydınlatmaları AVM'nin açık kaldığı süre boyunca kullanımda olmalıdır. Tasarım aşamasında düşük enerji tüketimli armatür kullanımı teşvik edilmelidir.

\subsection{Malzeme Seçimi}

Sürdürülebilir ürün, malzeme, enerji ve tasarım başlıklarında çevresel etkinin azaltılması ve operasyon maliyetlerinin düşürülmesini sağlayacak firsatları değerlendirmek temel amaçların başında gelmelidir. Tüm yüzeylerde kaliteli malzemeler kullanılmalıdır. Kiracılar tüm imalatlarını yönetmeliklere uygun olarak yürütmekle yükümlüdürler. Kiracıların imalatlarında kullanacakları malzemeler TSE (Türk Standartlarına Uygunluk Belgesi olan 
malzemeler), sürdürülebilirlik, engelli erişimine ve sağlık koşullarına uygun olarak seçilmelidir.

Alışveriş merkezi ortak kullanımlı yemek alanlarının genelinde ve yemek satış birimlerinin içinde kullanılan döşemelerin uzun ömürlü, bakım ve temizliği kolay, tasarım konseptine uygun bir malzeme olmasına dikkat edilmelidir (ULI, 1999). Seçilen zemin malzemesinin uygun kayganlık sınıfında olması gerekmektedir. Dükkân zemini ile AVM ortak dolaşım alanı zemininin birleşme noktası düzayak geçiş sağlayacak şekilde çözümlenmelidir. Kot farklılıkları ve profilli çözümler estetik açıdan uygun görülmemektedir. Geri çekilmeli giriş tasarımlarında dişarıda kalan zemin, ortak alan kaplamasına uygun/eşdeğer malzemeler ile yapılmalıdır.

Dükkânların duvarlarında kullanılan boya ya da duvar kâğıtları zemin, tavan renkleri ile uyumlu olmalı, kaygan olmayan, kir tutmayan, kiracı değişimlerinde yeni kiracının değişiklik yapmasını kolay hale getirecek niteliklerde olmalıdır (Beddington, 1991).

Servis tezgâhları dayanıklı malzemeden, girintisiz olarak tercih edilmelidir. Servis tezgâhı ortak alan sınırında yapılacak ise tüm cephe boyunca kesintisiz yerleştirilmeli, köşe dönüşlerinde tezgâh mümkün olduğunca geniş tutulmalıdır.

\subsection{Mobilya Tasarımı/Kullanımı}

Ortak kullanımlı yemek alanları, ortak bir oturma bölümü ve çevresinde yan yana, karşılıklı ya da tasarlanmış bir bölüm içinde dizilmiş olan sabit ve hareketli mobilyalar ile çevrelenmektedir. Amaç; oturma sayısı ve çeşitliliğini arttırırken müşteriler için de konfor sağlamakla beraber birbirine geçiş sağlayan, akışkan alanlar oluşturmaktır. Malzemeler doğal taş, yüksek basınçlı laminat (HPL), alüminyum, doğal ahşap, akrilik ve benzeri malzemelerden seçilerek kullanılır. Müşterilerin rahat ve sakin bir yemek yemesi için gerekli düzenlemelerin yapılması ve yemek yenildikten sonra ise müşterilerin kalkıp yerini hızlıca başkalarına devretmesine imkân sağlamak önemlidir.

Yerleşim planına göre mobilyalar, yemek bölümünün konsept ve tasarımına uygun olarak, sabit ve/veya hareketli olarak tasarlanır. Sabit bank oturma grupları; oturma yüzeyi minderli ya da mindersiz olarak mekân bölümlenmesine özel üçgen, daire, dikdörtgen veya kare formlarda çift yönlü serbest kullanımlı ya da L, I ve U formlarda tek yön kullanımlı olarak uygulanırlar. Oturma alanlarında, iki ya da dört sandalyeli oturma düzeni ile masa büyüklükleri ve sirkülasyon aralıkları belirlenir. Konsepte bağlı olarak gruplar için, beraber oturabilecekleri daha geniş ve uzun özel tasarım bar tipi masalar I, oval, yuvarlak ve üçgen tip olarak ya da mekâna özel formda tasarlanarak mekân kurgusuna yönelik kullanılırlar. Seçilen masa ve sandalye malzemeleri darbeye dayanıklı, yangın yönetmeliklerine uygun ve kolay temizlenebilen malzemelerden, sandalyeler ise gerektiğinde üst üste istiflenebilen özellikte tercih edilmelidir.

Ortak kullanımlı yemek alanlarında mekân bölünmeleri için kullanılan bölücü elamanlar; mekân, mobilya ve konsepte bağlı olarak kitaplık, bitki, süs ve bölücü eleman olarak tasarlanan sabit elemanlar olmanın yanı sıra aynı zamanda aydınlatma, tabela ve görseller içinde kullanılan ünitelerdir. Oturma alanlarının üzerinde ise görsel estetiği sağlamak için sabit elamanlara bağlanarak gölgelik etkisi veren düşey elemanlarla beraber de tasarlanarak kullanılırlar. Ana gövde yüksek basınçlı laminat (HPL), alüminyum, doğal ahşap, ferforje, akrilik ve benzeri malzemelerden seçilerek kullanır.
Alışveriş merkezlerinde her kesime hitap edecek tasarımlar yapılmalıdır. Özellikle nüfusun \%14'ünü oluşturan engelli bireyler için önlemler ve iyileştirmeler düşünülmelidir. Çünkü bu bireyler de bir tüketici olup, alışveriş merkezinden yararlanabilecektir. Engelli Tüketici Hakları Komitesi tarafından 2003 yılında yapılan bir araştırma engelli vatandaşların \%75'inin ara sıra, \%13'ünün hiç alışverişe çıkmadığını ve \%12'sinin ise düzenli alışverişe çıktığını ortaya koymuştur. Alışverişe hiç çıkmayan engelli bireylerin büyük çoğunluğunun zihinsel ya da görme engeline sahip olduğu araştırma ile ortaya konulmuştur (Bulut ve diğerleri, 2003). Yemek alanlarında engelli bireyler için tekerlekli sandalye alanlarına ve şarj ünitelerine de yer verilmelidir.

Yiyecek-içecek satışı yapan kioskların birçoğunun ortak kullanımlı yemek alanları içinde yer almalarından dolayı yemek bölümleri içinde önemli bir yere sahiptir. Kiosklar etkili bir duruş sergilemeli ve bu amaçla yapılan çok özel tasarımların ürünü olmalıdır. Açık ve içinde dolaşılabilen kiosk tasarımları teşvik edilmelidir. Ürün teşhiri tasarımında; servis elemanları, eviye, çay makinesi vb. teknik ekipmanlar görsel estetiği bozmayacak şekilde çözümlenmelidir. Kiosk çevresindeki oturma elemanları ve onları çevreleyen paneller kiosk konseptinin parçası ve ortak tasarımın tamamlayıcısı olacak şekilde çözümlenmelidir.

\section{Sonuç}

Gelenek ve göreneklerin, toplumsal davranışların değişmesi ile yeniden şekillendiği son yıllarda, alışveriş kavramı da yeniden tanımlanmakta ve yeni bir tüketici kültürünün ortaya çıkmasına neden olmaktadır.

Yeni oluşan tüketici kültürü, farklılaşan mekân ihtiyaçlarını, ürün ya da marka aramaktan daha çok sosyalleşebilecekleri kafe ve restoranlar olarak belirlemeye başlamıştır. Yapısal olarak bir kabuk işlevi görmekten ziyade daha çok aktiviteler bütünü tasarlamak, sosyal hayatı içinde barındıran, dış mekânı mümkün mertebe iç mekâna yansıtarak iç ve dış kurguyu bütünsel bir yaklaşıma getirmek, sokak kültürünü, sokak algısını yaşanmışlıklarla ve deneyimlerle çeşitlendirmek gerekmektedir.

Ofis, konut ve eğlence gibi fonksiyonları içeren karma projeler dahilindeki dördüncü kuşak alışveriş merkezlerinde hizmet veren yeme-içme alanları güçlü bir çekim gücüne sahip olduğundan diğer mağazalara katkı sağlayarak ortak bir sinerji oluşturmaktadır. Ziyaretçilerin bu alanlarda daha uzun vakit geçirmesi ciroların yükselmesine katkıda bulunmaktadır.

Alışveriş merkezi etkinlik alanları, genç nüfusun popülasyon yüzdesinin yüksek olduğu ülkelerde teknolojik gelişmeler ile sosyal ihtiyaçlar doğrultusunda sürekli değişmekte olup, yeme-içme mekânlarından bağımsız düşünülememektedir.

Yeni nesil alışveriş merkezlerinde değişen alışkanlık ve ihtiyaçlara kolayca uyum sağlayabilen, doğaya ve doğallığa öncelik veren, çevresi ile ilişkilendirilmiş, peysaj alanları ve bitkisel tasarımlarla kurgulanmış, kullanıcılara sokak dokusu ve deneyimini yaşatan iç-dış ayrımını aşarak akışkan hacimler sunan mekânlar oluşturmak gerekmektedir.

Alışveriş merkezi projelerinin farklı aktivite alanlarını kapsayan geniş ölçekli mekânlar bütününde, bu alanların doğru fiziksel ve altyapısal koordinasyonunun sağlanmasının yanı sıra enerji üretimi, kullanımı ve verimliliğine önem verilmesi, konsept bütünlüğünün, tutarlılığının korunması ve uzun vadeli işletme gereksinimlerinin gözetilmesi önem taşımaktadır. Doğru malzeme ve detay çözümlemeleri ile mekânlar birbirleriyle ilişkilendirilmelidir. 
Yapılan incelemelere göre; alışveriş merkezlerinin tasarımında ferahlık, uygun malzeme seçimi, renk kullanım ve mekân donanımı, müşterilerin konforunu arttırmaya yönelik mekân çözümlerinde önem taşımaktadır. Belli bir temaya sahip yemek bölümleri müşterilerin ilgisini daha fazla çekmekte ve alışveriş merkezinin daha çok talep görmesini sağlamaktadır.

Ortak kullanımlı yemek alanlarında çeşitli yiyecek ve içecek satan farklı markalarla çeşitliliği sağlayan kioskların yeterli sayıda bulunması yemek satış alanlarını hareketlendirmekte ve mekândaki boş alanların da verimli bir şekilde değerlendirilmesini sağlamaktadır. Kiosk çevresindeki oturma elemanları ve onları çevreleyen paneller kiosk konseptinin parçası ve ortak tasarımın tamamlayıcısı olacak şekilde çözümlenmelidir.

Ortak kullanımlı yemek alanlarında konsept bütünlüğü içinde; vitrin/cephe tasarımları, mağaza içinin daha iyi algılanmasını sağlayacak açıklık seviyesinde, müşteriyi etkileyen, davetkâr çözümlerle desteklenmelidir. Mağaza isimlerinin algılanabilir biçimde kurgusu, müşteriyi rahatsız etmeyen ve ürünleri öne çıkaran aydınlatma seviyelerinin belirlenmesi, sürdürülebilir malzeme kullanımı, malzeme çeşitliliği ve oturma alanlarında sabit oturma ve masa gruplarının kullanımı, hareketli mobilyalarda çeşitlilik sağlanması, çocuk mobilyalarının kullanımı, tekerlekli sandalye kullanıcıları için şarj ünitelerinin bulunması ve oturma alanlarının çeşitli görseller ve bitkilerle etkileyici bir hale getirilmesi önemlidir. Tercih edilen her malzeme ve ürünün TSE, sürdürülebilirlik, engelli erişimi ve sağlık koşullarına uygun olarak seçilmesi ve belirlenen standartlara göre uygulanması gerekmektedir. Mağaza tasarımlarında AVM geneli için planlanan standartın sağlanabilmesi amacıyla, kiracı mağaza konseptleri AVM yönetimi ile iş birliği içinde yürütülmelidir.

Mimari sistemlerin kurgu ve planlama ile bütünleşmesi sonucu ortaya çıkan alışveriş merkezleri, ticari hedeflerine ulaşabilmek için tüketici beklentilerine insan odaklı bir yaklaşım içinde; çocuk, aile, gençler ve engelli bireylerin ihtiyaçlarına ve fonsiyonellik ve estetik bakımından da yanıt verebilecek şekilde tasarlanmalı ya da yenilenmelidir (Durukan, 2015). Yaratıcılık ve yenilikler olabildiğince ön plana çıkarılmalıdır.

Sonuç olarak alışveriş merkezlerinin müşterilerinin ilgilerini canlı tutabilmek adına beş yılda bir yenilenmesi gerektiği tavsiyeleri dikkate alındığında; her dönemin etkin olan bir eyleminin, ihtiyacının ortaya koyduğu oluşumların, rekabetin devam ettirilebilmesi için yenilenmeye ve yönlendirilmeye ihtiyacı olduğu ve bu yönde çalışmalar yapılarak işlerliğin sürdürülebileceği görülmektedir. Gelirin düzenli hale getirilebilmesi için, her geçen gün gelişen ve değişen diş dünya, perakende sektörü tarafından takip edilmeli, tüketici taleplerindeki değişikliklere, ihtiyaçlara cevap verecek şekilde hareket edilmelidir. Belli zaman aralıklarında yapı içerisinde tadilatlar, iyileştirmeler yapılarak güncel ve modern malzemelerin kullanılması ile farklılık yaratılmalı, müşteri kitlesini koruyarak yeni müşteri çekme hedefleri içinde ve tüketici talep ve beğenilerine yönelik sürekli devinim içinde olunmalıdır. Ayrıca başarılı bir alışveriş merkezinin kurgusu mimarlar, iç mimarlar, şehir planlamacıları, sosyologlar, perakendeciler, yatırımcılar ve diğer ilgili disiplinler bir araya gelerek oluşturulmalıdır. Yapılan araştırmalar, günümüz koşul ve tüketici eğilimleri çerçevesinde değişimi takip eden ve kendini yenileyebilen alışveriş merkezlerinin rakiplerine fark atarak kolayca fark edilebileceklerini göstermektedir.

\section{Teşekkür}

Doktora tez çalışmamdan yararlanarak hazırlamış olduğum bu makalede emeği geçen tez danışmanım Prof. Dr. İpek FITÖZ'e, her daim beni destekleyen Doç. Dr. Saadet AYTIS ve Dr. Öğr. Üyesi Ayşegül DURUKAN'a teşekkürlerimi sunarım.

\section{Kaynakça}

Arslan, F.M., (2004). Măgazacılıkta Atmosfer, İstanbul, Derin Yayınları

Ayt1s, S. (2008). Günümüz Alışveriş Merkezleri: Dün, Bugün, Yarın Tasarım/Uygulama Esaslart, Arkitekt, Mart-Nisan, Say1: 516, İstanbul, Şafak Gazetecilik ve Matbaacilık.

Beddington, N., 1991. Shopping Centres: Retail Development, Design and Management, Oxford: Butterworth Architecture.

Bocock, R., (1947). Tüketim, Ankara, Dost Kitabevi Yayınları

Bulut, B., Doğan,C., Şahin,F. ve Genç, N., 2003. Engelli Tüketicinin Haklar1, Tüketiciler Derneği.

Cochrane, W W. ve Bell, C.S., 1956. The Economics of Consumption, MCGraw- Hill Book Company, New York.

Coleman, P., (2006). Shopping Environments: Evolution, Planning and Design, Architectural Press, London.

Durukan A., (2015). Alışveriş mekânı tasarımında insan odaklı yaklaşım: 'deneyimsel alışveriş mekânları'. 1. Ulusal İ̧̧ Mimari Tasarım Sempozyumu, (s.454-459). Trabzon, Türkiye.

Durukan A.,( 2018). Gelişim sürecinde alışveriş mekanları ve günümüzün deneyimsel alışveriş mekanı anlayışı. Turansam: Uluslararası Bilimsel Hakemli Dergisi, vol.10, pp.740747, 2018.

Göka, Ş., (2001). Insan ve Mekân, İstanbul: Pınar Yayınları

Gruen, V. ve Smith, L., (1960). Shopping Towns USA, New York: Reinhold Coorparation

Kaplanseren, E., (2020, 14 Şubat). Bu teknolojiler alışveriş alışkanlıklarını değitirecek. Milliyet Gazetesi. Erişim adresi https://www.milliyet.com.tr/teknoloji/bu-teknolojileralisveris-aliskanliklarini-degistirecek-6144928

Özen, A. (2006). Mimari Sanal Gerçeklik Ortamlarında Algl Psikolojisi, Bilgi Teknolojileri Kongresi IV. Akademik Bilişim, Denizli.

Pekpostalcı, A. (2015a). Alışveriş Mekânlarının Tasarımında Deneysel Pazarlama Metodu ve Örnekler Üzerinden Analizi (Doktora tezi). Mimar Sinan Güzel Sanatlar Üniversitesi, Fen Bilimleri Enstitüsü, İç Mimarlık Ana Bilim Dalı, İstanbul.

Pekpostalcı A., (2015b). Deneyimsel pazarlama metodu ve bu metodun alışveriş mekânları tasarımında kullanımı. 4. Ulusal İç Mimarlık Sempozyumu, (s.143-160). İstanbul, Türkiye.

Satıcı, Ö. (2000). Tüketici Davranışlarını Etkileyen Faktörler, doi: 10.13140/RG.2.1.3974.2804

Tokol, T. (1996). Alışveriş Merkezleri, Çevre ve Mekân İlişkisi (Yüksek lisans tezi). T.C. Marmara Üniversitesi, Sosyal Bilimler Enstitüsü, İç Mimarlık Ana Bilim Dalı, İstanbul.

ULI, (1999). Urban Land Institute Shopping Center Development Handbook, Washington, D.C.

URL 1. http:www.lebonmarche.com/decouvrir/historie.html, (Erişim Tarihi: Mart, 2020). 